UDC 550.83

\author{
V. D. Soloviev ${ }^{1, \text { * }}$, V. G.Bakhmutov ${ }^{1,2}$, I. N. Korchagin ${ }^{1}$, T. P. Yegorova ${ }^{1}$ \\ ${ }^{1}$ S.I. Subbotin Institute of Geophysics, National Academy of Sciences of Ukraine, \\ 32 Akad. Palladin Avenue, Kyiv, 03142, Ukraine \\ ${ }^{2}$ State Institution National Antarctic Scientific Center, Ministry of Education and Science of Ukraine, \\ 16 Taras Shevchenko Blvd., Kyiv, 01601, Ukraine \\ *Corresponding author: valera@igph.kiev.ua
}

\title{
NEW GEOPHYSICAL DATA ABOUT THE PACIFIC MARGIN (WEST ANTARCTICA) MAGNETIC ANOMALY SOURCES AND ORIGIN
}

\begin{abstract}
During the seasonal work in the Ukrainian Antarctic expeditions (1997-2012), a significant amount of geological and geophysical studies were carried out. The main objective of the study is to obtain new data on the distribution of deep heterogeneities in the structures of the region. It's allowed to construct the geophysical models and to discuss the existing ideas about the stages of formation and evolution tectonic structures of the West Antarctica near the Antarctic Peninsula (AP). New geophysical models of the Earth's crust were used to study the possible nature of the Pacific Coast magnetic anomaly (PMA) near the AP. The results of magnetic, seismic and geoelectric surveys in the region of the Antarctic Peninsula showed that active tectonic processes in the Meso - Cenozoic led to the of PMA magnetic sources forming along the edge of the AP. The spatial heterogeneity of the various segments of PMA can also be associated with a variety of depth, thickness and magnetic susceptibility of individual units that form the source of regional anomaly. The magnetic PMA sources in the Earth's crust can be limited in depth (up to $8-10 \mathrm{~km}$ ) and consist of a series of bodies with different age, composition and magnetization. The shape of the PMA anomalies is significantly affected by numerous local intrusions located in the upper part of the earth's crust. In certain segments of the PMA, they form an additional horizon of magnetized bodies associated with the processes of young volcanism in the structures of the continental margin. Conclusions. The materials of geophysical surveys and complex geological and geophysical models of the earth's crust and upper mantle were analyzed, which made it possible to identify structural features, evolution, and geodynamic processes of the development of regional structures, as well as to obtain new data on the possible nature of PMA. The total anomaly name (PMA) can formally integrate anomalies of different ages and origins. Numerous local intrusions of young (Cenozoic) age form an additional horizon of magnetized bodies associated with volcanic processes at the top of the crust. Some segments of the PMA may be associated with the processes of tectonic changes near the Antarctic - Scotia paleo-plate boundary, as well as tectonic and magmatic activity in the areas of paleorift structures detection. New geophysical results for different PMA - segments from the Palmer Land to Powell Basin were used to summarize current ideas about the sources and origins of this positive magnetic anomaly.
\end{abstract}

Keywords: West Antarctica, Antarctic Peninsula areas, Pacific Margin Magnetic anomaly, geophysical models, deep crustal structure.

\section{INTRODUCTION}

The magnetic anomalies and their sources spatial distribution patterns at the West Antarctica region are an effective tool for inner geological structure and paleo-geodynamic processes studying. In recent years the ADMAP - project database was significantly en-

(C) V. D. SOLOVIEV, V. G.BAKHMUTOV, I. N. KORCHAGIN, T. P. YEGOROVA, 2018

riched by new magnetic surveys data for the Pacific margin of the Antarctic Peninsula areas. Satellite, aero and ship-born potential field data have been compiled into publicly available databases of the ADMAP and ADGRAV projects and were published in many papers (Ferraccioli et al., 2006, Ghidella et al., 2011, Golynsky et al., 1999, 2012).

The data bases materials were used to determine the new details of the early history of possible spread- 
ing of the Bellingshausen plate relatively Pacific plate and the processes of spreading between East and West Antarctica (Golynsky et al., 2012). These materials are important to determine the magnetic anomalies distribution within the structures of the Pacific margin of the West Antarctica, where part of the territory is not covered by the detail surveys. These data gave a new important information about the geological structure, formation history of the basic structures and features of geodynamics of West Antarctica (Ghidella et al., 2011, Jordan et al., 2014).

We analized the Pacific Margin anomaly (PMA) spatial distribution and its deep sources, modelling the deep structure of the continental margin of the Antarctic Peninsula (Levashov et al., 2008, Soloviev et al., 2017, Udintsev et al., 2010, Yegorova et al., 2011, 2013).

\section{MAGNETIC MODELS AND PMA-SOURCES DATA}

A spectacular feature of the magnetic field of the AP continental margin is a wide (nearly $120 \mathrm{~km}$ in width) belt of strong magnetic anomalies. This is so-called Pacific Margin anomaly (PMA) by (Maslanyj et al., 1991) or West Coast Magnetic Anomaly (WCMA) by (Renner et al., 1985) - an arcuate belt of positive magnetic anomalies that extends $3800 \mathrm{~km}$ from the South Orkney Island to Thurston Island (Fig. 1). Wide strip of magnetic anomalies with amplitude up to 1900 nT usually characterize this anomaly along the Central Domain's of western margin of the Antarctic Peninsula.

In the NW part of AP between Anvers Island and the northern termination of the Bransfield Strait (Fig. 2) the PMA splits into two branches - the Western anomaly of high magnitude (500-1500 nT) and the Eastern anomaly of lower magnitude (500-900 nT). The wide of these anomalies sources is $30-50 \mathrm{~km}$ (Garrett, 1990).

The total length of PMA-anomaly along the coast of the Antarctic Peninsula is more than $2200 \mathrm{~km}$. Recent geophysical and geological studies show that its sources are a part of the magmatic arc that includes two or three separate autonomous areas, which were connected in the Middle Cretaceous (Ferraccioli et al., 2006).
Two extended positive anomalies (with 400-1300 nT intensity) are distinguished on the anomaly magnetic field map for the northern part of the continental margin of the AP (Fig. 2). The SSMA is located near the South Shetland Islands with intensity reaching 1300 nT between the Smith and Snow Islands. The intensity decreases to $700 \mathrm{nT}$ near the King George Island (Catalan et al, 2013).

The PCMA extends in the direction south-west north-east along the Antarctic Peninsula above the structures of the platform part of the Bransfield Strait (Fig. 2). The average intensity of the magnetic anomalies of this zone is about 400nT, the maximum values (up to 800nT) are characteristic for the southwestern part of the Strait. The anomaly of SSMA looks like a homogeneous zone with sustained linearity (Fig. 2) that is confirmed by the results of aeromagnetic surveys (Gràcia et al., 1996), where $500 \mathrm{nT}$ isoline separates the position of the linear anomalous zone north of the South Shetland Islands (SSMA anomaly) with individual maxima up to $1100 \mathrm{nT}$.

The PCMA preserves only the general direction of the strike without predominant linearity. In some areas, it breaks up into separate oval nodes, which indicates significant fluctuations in the depths of occurrence of magneto active bodies or a significant heterogeneity of their magnetic properties.

In the central part of the Bransfield Strait, this anomaly is represented by a series of separate, sufficiently isolated from each other, anomalies with a maximum amplitude of 300-500 nT. High-frequency positive magnetic anomalies are located above a group of isolated underwater volcanoes in the central part of the Strait. The average intensity of magnetic anomalies over volcanic structures (Fig. 2) is $300 \mathrm{nT}$, with varying from $135 \mathrm{nT}$ (volcano $\mathrm{F}$ ) and $450 \mathrm{nT}$ (volcano G) to 850-1250 nT (Orca volcano).

New interpretation for the Mesozoic evolution of the AP geology and new airborne geophysical data (gravity and magnetic fields) reveal evidences of crustal growth of the AP by Mesozoic arc magmatism and terrane accretion along the paleo-Pacific margin of Gondwana (Ferraccioli et al., 2006, Vaughan et al., 1998). The paleo-Pacific margin of Gondwana is now recognized as a long-lived accretionary orogen, ac- 


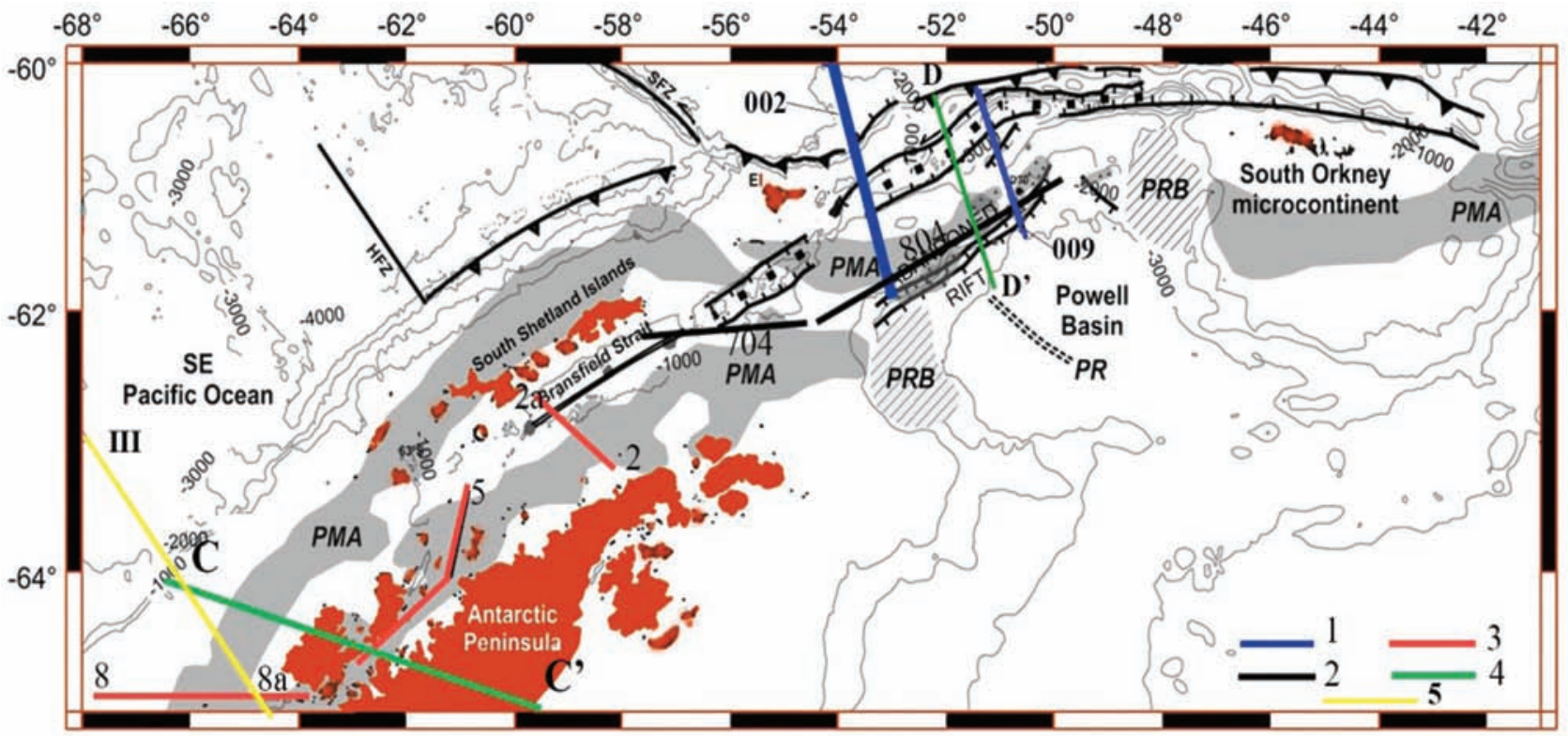

Fig. 1. The PMA distribution at the continental margin of the Antarctic Peninsula and Powell Basin, by (Lodolo et al., 2015): 1 seismic profiles SA-500-002 and SA-500-009, by (Civile et al., 2012); 2 - profiles (704, 804) of marine magnetic surveys; 3 geoelectric profiles (8-8a, 5, 2-2a), by (Levashov et al., 2008); 4 - profiles (C-C', D-D') of aeromagnetic surveys, by (Johnson, 1999); 5 - profile - III by (Yegorova et al., 2013)

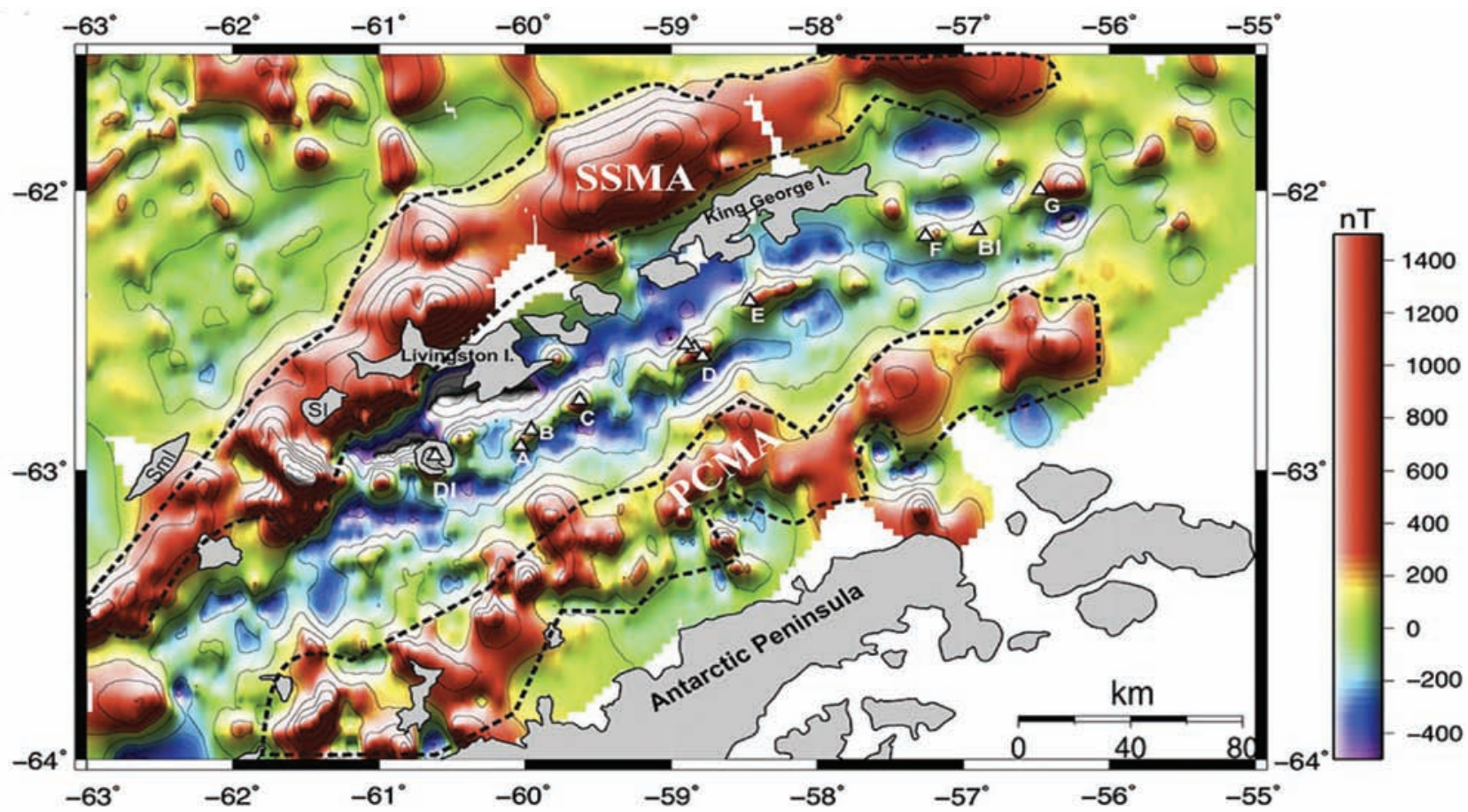

Fig. 2. Magnetic anomalies map for Bransfield Strait region by (Catalan et al, 2013). The triangle marked position over- and underwater volcanoes: A - volcano Ex; C - volcano Orca; D - volcano Three Sisters; E - volcanic ridge Hook; F, G - separate volcanic structures. Islands: DI - Deception Island; BI - Bridgman Island; SI - Snow Island; SMI - Smith Island. Regional magnetic anomalies: SSMA - South Shetland Magnetic Anomaly; PCMA - Pacific Coast Magnetic Anomaly 
tive from Neoproterozoic times at least. Accretionary orogenesis, driven by paleo-Pacific plate processes, continued right through Gondwana break-up, as it was argued by Vaughan et al. (2005).

The Pacific margin of the AP is marked by belts of strong gravity and magnetic anomalies attributed to a magmatic arc system consisting of a series of plutons (Garrett, 1990, Renner et al., 1985) comprising the giant AP batholith. In Johnson (1999) it was proposed that an original single batholith was split along its axis to form the parallel magnetic anomalies, although he also discussed an alternative hypothesis that the parallel anomalies are original features representing two separate arcs. A third model in which the western branch of the PMA is a Cretaceous allochthonous terrane has also been suggested (Yegorova et al., 2013).

It is also assumed that different AP crustal blocks within segments of PMA developed as autochtho-
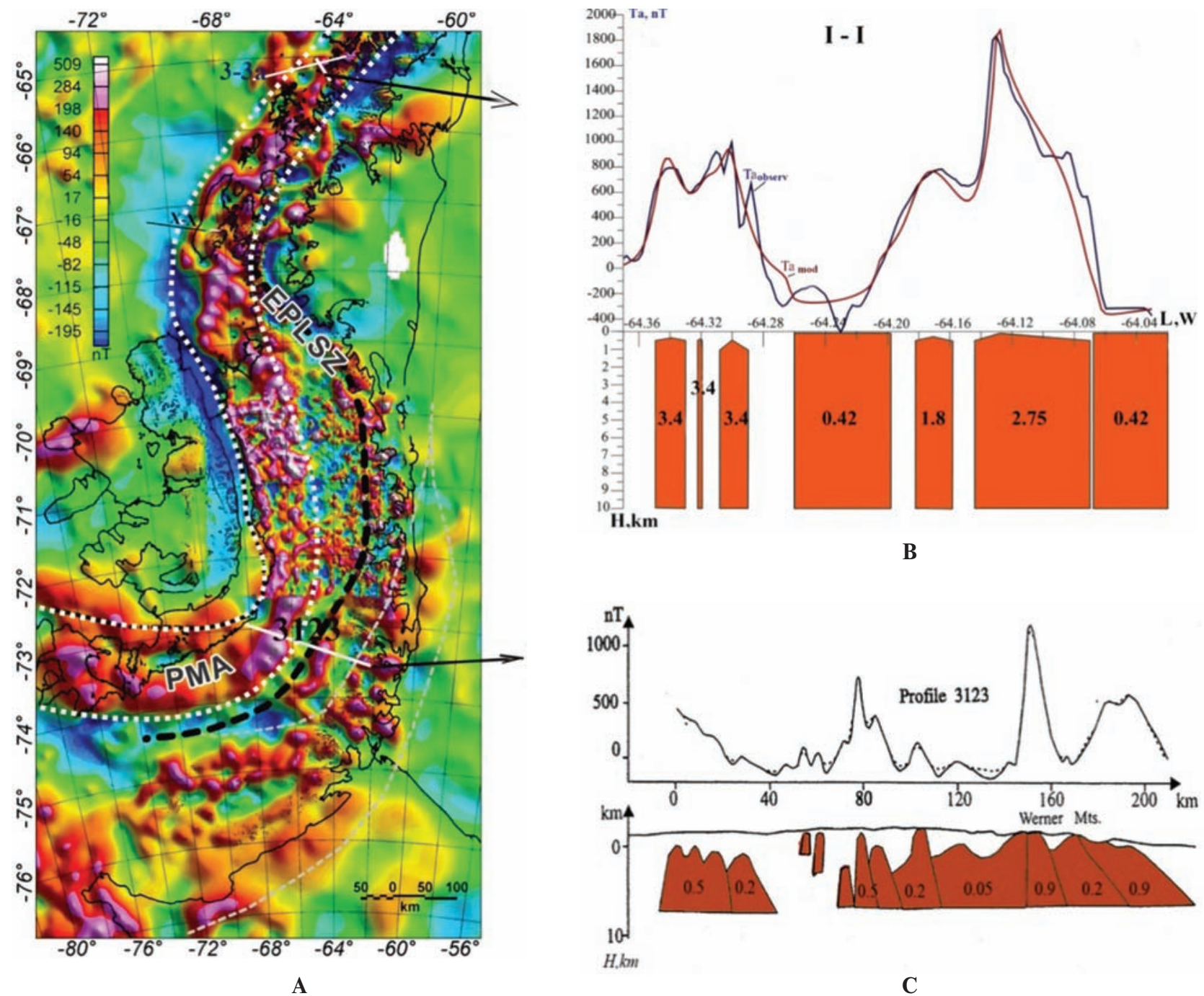

B

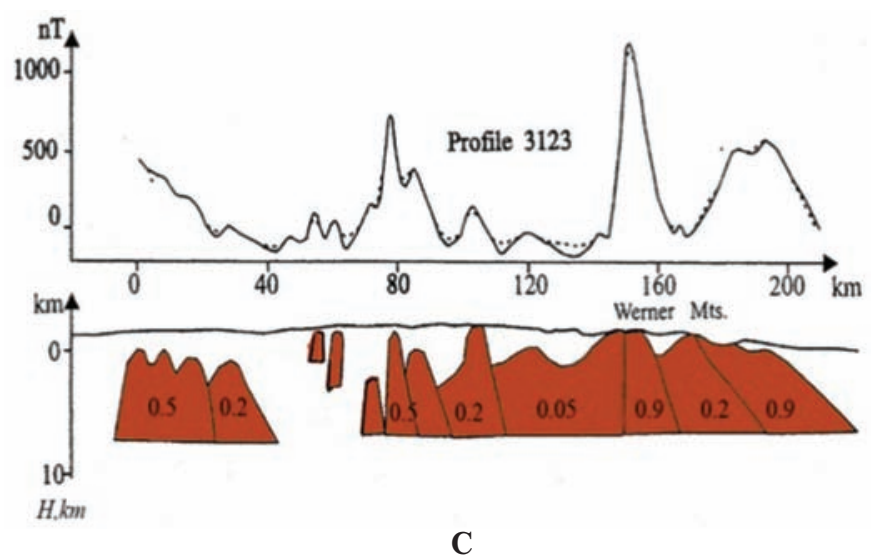

Fig. 3. Magnetic anomaly map (A) of Antarctic Peninsula and adjacent structures by (Ferraccioli et al., 2006, Jordan et al, 2014) according to ADMAP compilation by (Golynsky et al., 2012) and profiles (B, C) across the PMA. 3-3a - profile VERS location. B - interpretation profile I- I with block magnetization values (A/m) near Ukrainian Antarctic Akademik Vernadsky station, see location on Fig. 3A, 4; C - interpretational profile 3123 across the PMA in the SE part of Palmer Land AP with body susceptibilities $\left(10^{-3} \mathrm{SI}\right)$, by (Golynsky et al., 1999). EPLSZ - East Palmer Land Shear Zone 


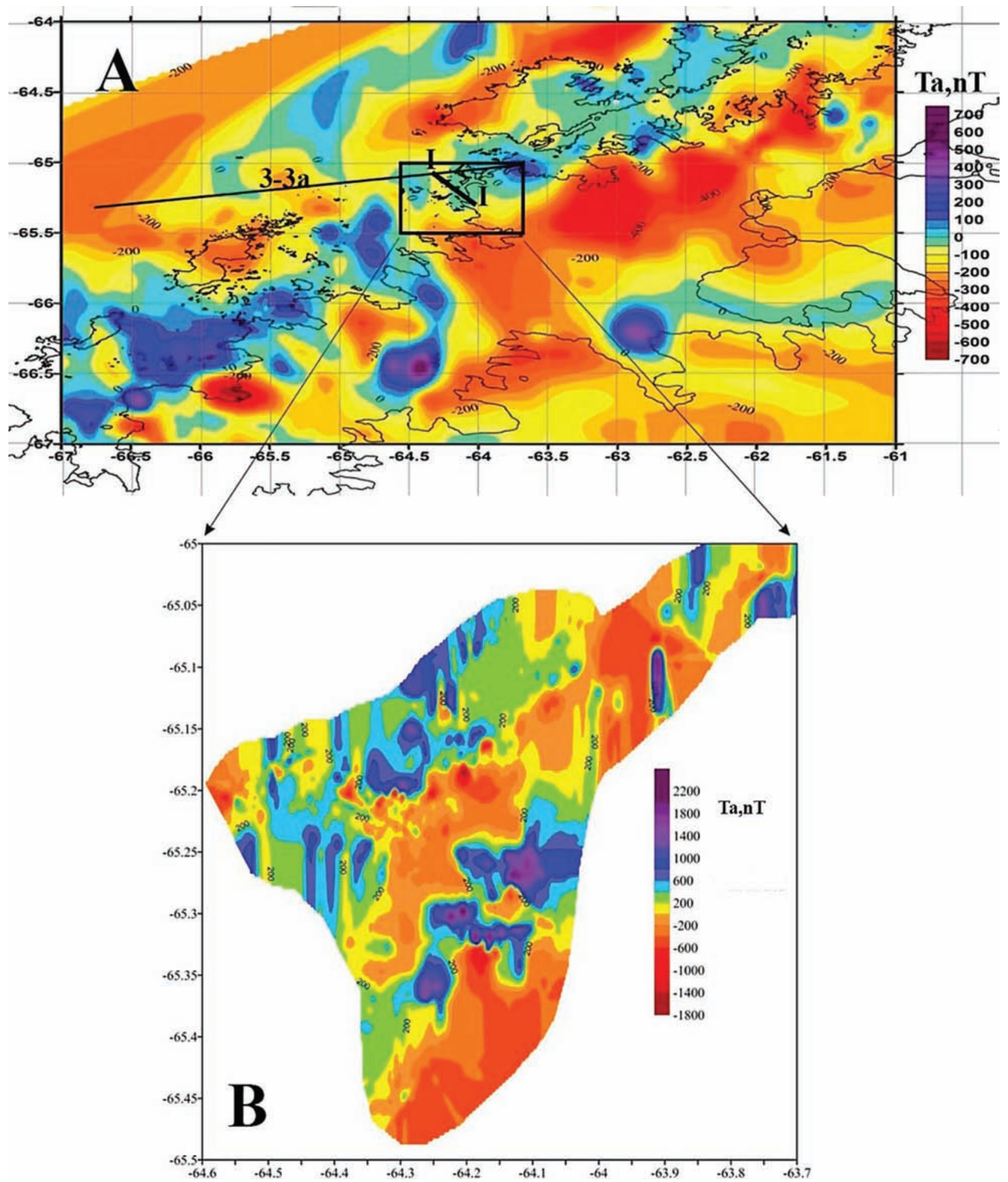

Fig. 4. Magnetic anomaly map of the Antarctic Peninsula (Anvers Island area) based on aeromagnetic (Johnson, 1999) data (A) and map of the Argentine Islands Archipelago (B) by the magnetic surveys results near Vernadsky station 
nous sequences on the remnant Gondvanian margin, not through terrane accretion of allochthonous bodies (Burton-Johnson et al., 2015).

Active tectonic processes in the Mesozoic - Cenozoic resulted in the complex evolution and the magnetic sources of PMA along the AP margin forming. The magnetic sources of PMA along the AP margin were formed during not only Cretaceous, but also in Paleogene - Neogene main phases of magmatic activity.

The volcanic activity in West Antarctica and adjacent oceanic areas started in the Oligocene (Udintsev et al., 2010) and could be related to decompression melting of the asthenosphere. Eruptions of alkaline magmas along the AP appear be resulted from shallow melting of the primary mantle, which was partially depleted (Sushchevskaya et al., 2016).

The PMA may be caused by strong magnetization of a chain of batholiths, which were formed in the subduction environment at the shelf zone of the Mesozoic-Cenozoic magmatic arc of the AP (Garrett, 1990, Renner et al., 1985). Magnetite-bearing gabbro and diorites are the main rock types composing the batholiths. A correlation was found between the PMA positive anomalies and exposures of gabbro (Johnson, 1999). Calculations show that the PMA may be explained by bodies with magnetic susceptibility of $0.055-0.075$ SI and lower boundary occurring at the depth of nearly $20 \mathrm{~km}$, the estimated depth of the Curie isotherm (Johnson, 1999, Yegorova et al., 2013).

Recent airborn geophysical studies confirm this interpretation and reveal the AP batholith as a composite magmatic arc terrane comprising two distinct arcs, separated by $>1500 \mathrm{~km}$ - long suture zone (Ferraccioli et al., 2006). Suturing of two arcs against the Gondwana margin caused the mid - Cretaceous Palmer Land orogenic event (Ferraccioli et al., 2006). It was also suggested that the PMA in Palmer Land could been associated with an intense phase of extension in the early Cretaceous (Vaughan et al., 1998).

New geophysical results for different PMA segments from the Palmer Land to Powell Basin (Fig. 1-3) may generalize current ideas of sources and origin of this positive magnetic anomaly associated with the arc batholith.
The magnetic profile 3123 (Fig. 3, C) crossed the PMA in the southeastern part of the Palmer Land of Antarctic Peninsula. Separate bodies of high magnetic susceptibility values and depth of $8-10 \mathrm{~km}$ are sources of the anomalies (Golynsky et al.,1999).

These values differ from other PMA source model parameters, where the depth of magnetized (up to $2.0 \mathrm{~A} / \mathrm{m}$ ) batholith may be up to $20-25 \mathrm{~km}$ (Garrett, 1990). Magnetized body of high magnetic susceptibility is formed the most expressive amplitude magnetic anomaly up to 1600-1800 nT (Fig. 2, 3B, 3C) as also in other places along the coast, where they may be connecting with exposed Cretaceous gabbro (Golynsky et al., 1999).

Near the Vernadsky station (profile I-I, Fig. 3, 4), the values of remanent magnetization (up to $3.4 \mathrm{~A} / \mathrm{m}$ ) can be explained by the gabbro intrusions. The highest values of magnetic parameters $\left(\mathrm{J}_{\mathrm{n}}\right.$ reaches $7 \mathrm{~A} / \mathrm{m}$ ) characterize the outcrops of gabbros. Another group of bodies with magnetization values varying from 2.75 to $1.7 \mathrm{~A} / \mathrm{m}$ may refer to a gabbroides group. Their magnetic susceptibility corresponds to the range of $0.03-0.1 \mathrm{SI}$ (based on measurements of rock samples from outcrops in the area of research) (Shpyra et al., 2014).

Studies of our collection of Mesozoic and Paleocene intrusive and volcanogenic rocks (more than 500 samples) in the area of the Ukrainian Antarctic Akademik Vernadsky station have shown that the differences in the magnetic characteristics of rocks for petrographic groups are associated with an increase in basicity (acidic to basic) rocks. The values of the magnetic susceptibility increase from 0.02 to 0.068 SI, natural remanent magnetization - from 0.16 to 2.08 A / m (Shpyra et al., 2014).

These data are in good agreement with the results when PMA sources characterizing as highly magnetically susceptible Early Cretaceous gabbroic and tonalitic-granodioritic extensional plutons produced during a peak in magmatic activity (Jordan et al., 2014).

The spatial unity of PMA with the pluton outcrops may indicate that it was formed at this time, unlike other PMA segments formed in the Late Jurassic (Garrett, 1990) or in the Tertiary period (Storey et al., 1985).

The C-C' profile (Fig. 5) is located in the central part of the Antarctic Peninsula (Anvers Island re- 
gion). It was shown (Johnson, 1999) that the sources of PMA anomalies can be modeled by magneto active bodies with a susceptibility of about $0.055-0.065$ SI and the upper edge depth from 0 to $6 \mathrm{~km}$ and a depth of lower edge of about $20 \mathrm{~km}$, which is close to the expected Curie isotherm depth (Fig. 5). Some intrusions (associated with batholiths) rise from a depth of about $15 \mathrm{~km}$ and form local bodies, which are clearly reflecting in magnetic field anomalies.

Magnetite-enriched gabbros and diorites are the main types of rocks composing batholith. The values of the magnetic susceptibility for modeling used are in good agreement with the measured values of the magnetic susceptibility (from 0.01 to $0.23 \mathrm{SI}$ ) for rock samples of gabbro-diorite groups of the Antarctic Peninsula (Johnson, 1999, Maslanyj et al., 1991, Vaughan et al., 1998, Shpyra at al., 2014).

The AP continental margin was well studying by geophysical methods (seismic and potential fields data). There are many different crustal and upper mantle geophysical models with several geophysical parameters using (Yegorova et al., 2011, 2013).

Here we show only one geophysical model along the interpretation profile (III-III, Fig.6) that crossed the continental margin of the AP south of Anvers Island where seismic refraction and reflection data were obtained. These seismic data helped to constrain the geometry of 2-D gravity and magnetic models that are based on satellite-derived free-air gravity anomalies and total magnetic field anomalies data (Yegorova et al., 2011, 2013).

The model of deep crustal structure (Fig. 6) shows the source of the western branch PMA in the form of a block width of $80 \mathrm{~km}$, which is at depth from 5 to $25 \mathrm{~km}$ with a magnetic susceptibility of 0.074 SI - typical for the intrusive rocks (gabbro-diorite). The source of the eastern branch of PMA, lies at a depth of 5-18 (20) $\mathrm{km}$ and has a magnetic susceptibility of $0.065 \mathrm{SI}$ (Fig. $6,280-350 \mathrm{~km})$. The simulation results showed that PMA branches correspond crust with different thickness. In the PMA (e) crustal thickness is about $35 \mathrm{~km}$ and has the same crustal structure as the AP itself.

In the PMA (W) thickness of the crust is significantly $(10-15 \mathrm{~km})$ less. Zone of large gradient magnetic field (Fig. 6, $300 \mathrm{~km}$ ) controls the position of the fault zone between two blocks of crust with different thickness.

The modeling results (Fig. 6) indicate that the magnetic bodies are located in the upper and middle crust (up to $20-25 \mathrm{~km}$ ) and consist mainly of basic rocks (diorite, gabbro and gabbro-diorite).

Tectonic interpretation of these data indicates that the different branches of PMA formed in the Early Cretaceous in structures, were separated by a fault zone. West PMA branch is located within the extension unit, and east - within the Gondwana block. Magnetic anomalies of the PMA are related to a later magmatic modification of the crust by intrusions of mafic rocks into the crust of AP continental margin following collision between Gondwanian block and the suspect accreted terrane.

Western and eastern PMA-branches may correspond to different crustal blocks associated with predominantly Cretaceous magmatic intrusions of basic rocks to the continental margin of the Antarctic Peninsula structures. The western branch of the PMA may be a Cretaceous allochthonous terrane (Yegorova et al., 2011, 2013).

Profile 804 (Soloviev et al., 2017) crossed the PMA (E) branch of regional anomaly (Fig. 7). Bodies with a wide range of magnetic magnetization, which are located at depths of $0.5 \mathrm{~km}$ to $8-10 \mathrm{~km}$, may be the sources (intrusions) of intensive local magnetic anomalies.

We can assume the presence of several phases of magmatic activity with two horizons of magnetized bodies' formation at depth from $0.5 \mathrm{~km}$ to $4 \mathrm{~km}$ (Fig. 7).

The existence of high-amplitude and high - frequency magnetic anomalies may be connected with shallow plutons and volcanoes, consistent with gabbros and other outcrops of the magnetite-bearing rocks (Johnson,1999). This result is confirming by seismic data along profile SA-500-002 (Fig. 8), which crossed the eastern branch of PMA and profile 804.

Series of volcanic structures located along the Antarctic - Scotia Plate border (Civile et al., 2012) were discovered here by seismic data. The age of alkaline basalts here does not exceed 4,0 Ma. Most likely, they were forming during tectonic activity processes at the paleo-boundary of Antarctic - Scotia plates.

ISSN 1727-7485. Ukrainian Antarctic Journal. 2018, № 1(17) 


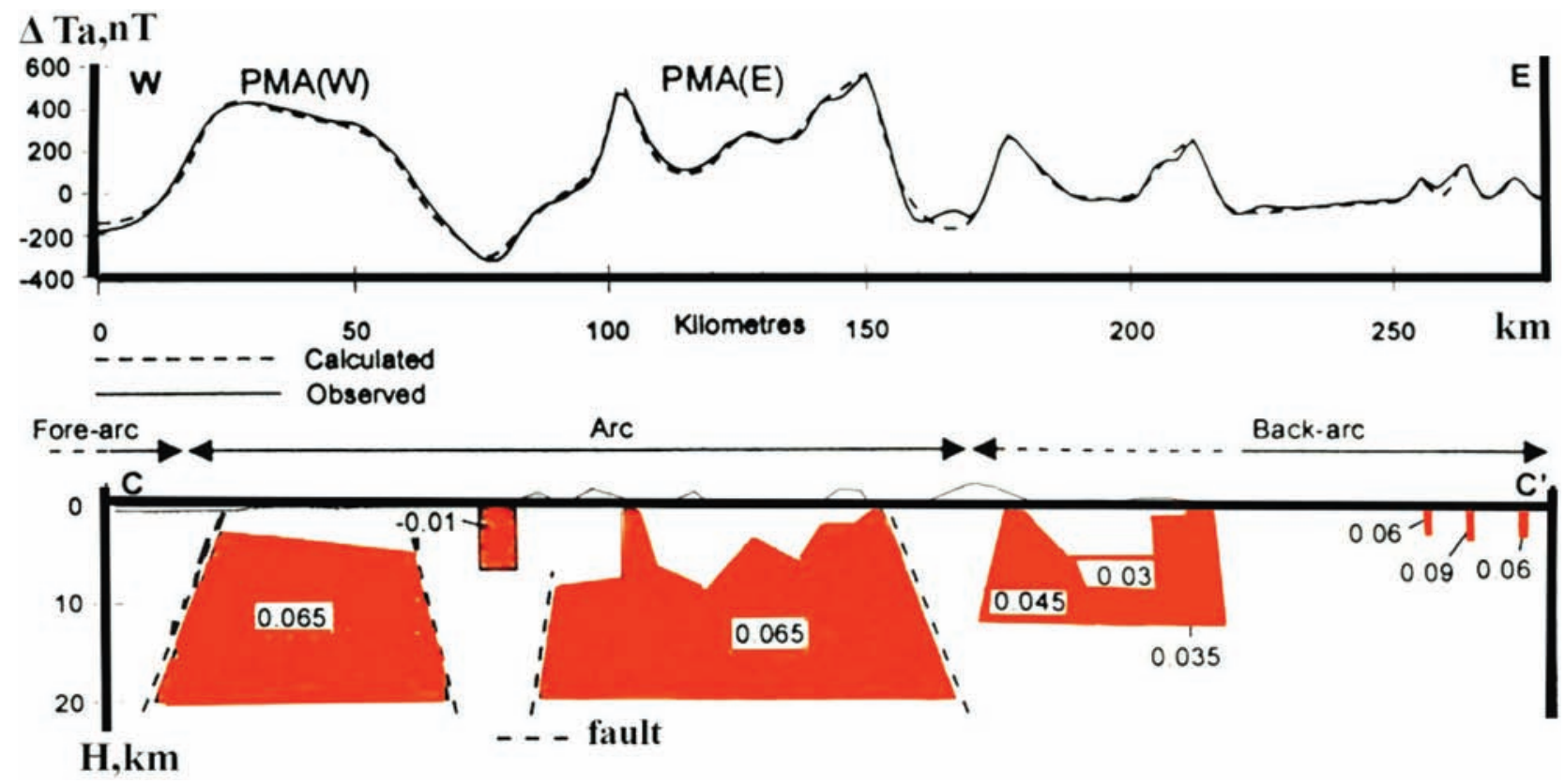

Fig. 5. The magnetic anomalies PMA (W) and PMA (E) along the interpretation profile C-C 'and the magneto active layer model for these anomalies, by (Johnson, 1999). Profile location - on Fig. 1

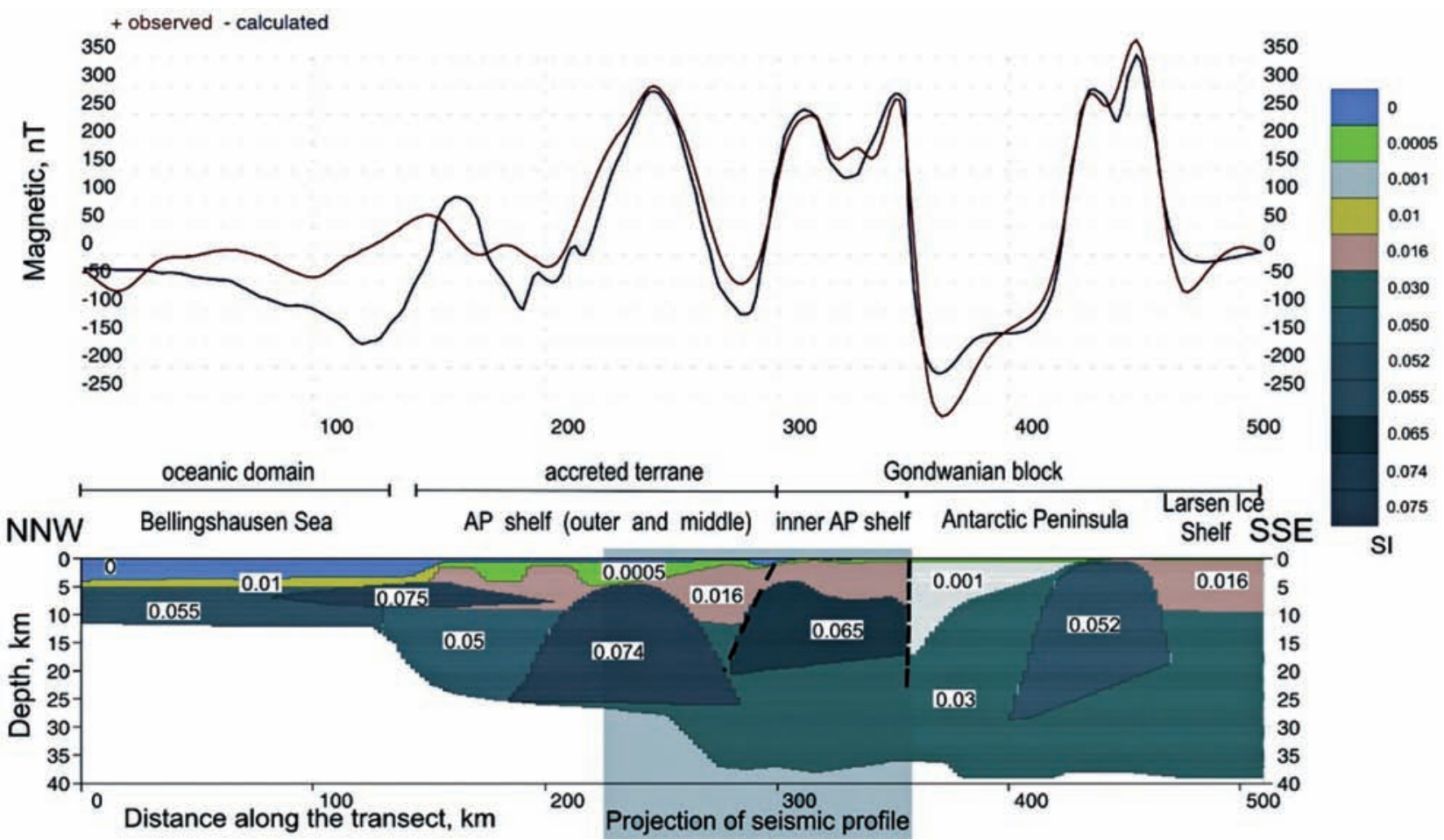

Fig. 6. Magnetic model for the crust from Bellingshausen Sea to Antarctic Peninsula, profile III-III. The geometry of main layers is constrained by seismic model on DSS-13 profile (Yegorova et al., 2011, 2013). Numbers on the cross-section indicate magnetic susceptibility in SI units. Location of profile III-III - on Fig. 1 


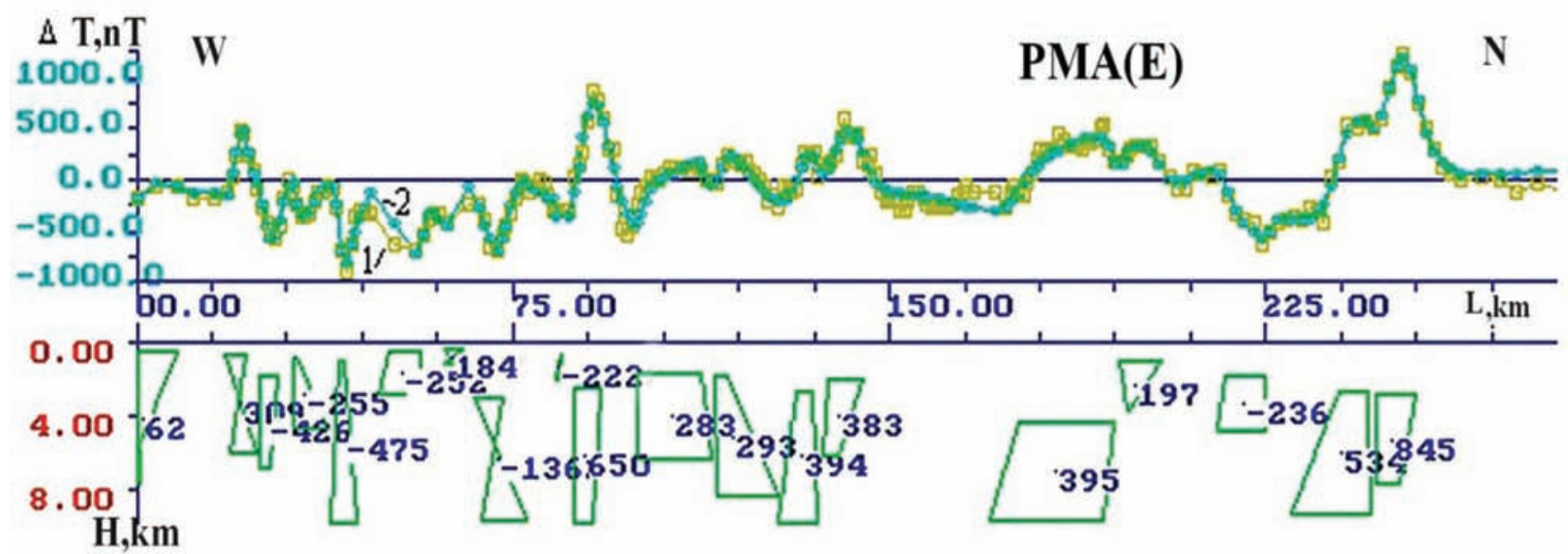

Fig. 7. Formal interpretation results for magnetic anomalies on profile 804 (Powell Basin). 1 - observed anomalies; 2 - calculated anomalies. The numbers - simulation remanent magnetization $\left(10^{-2} \mathrm{~A} / \mathrm{m}\right)$. Location of profile - on Fig. 1

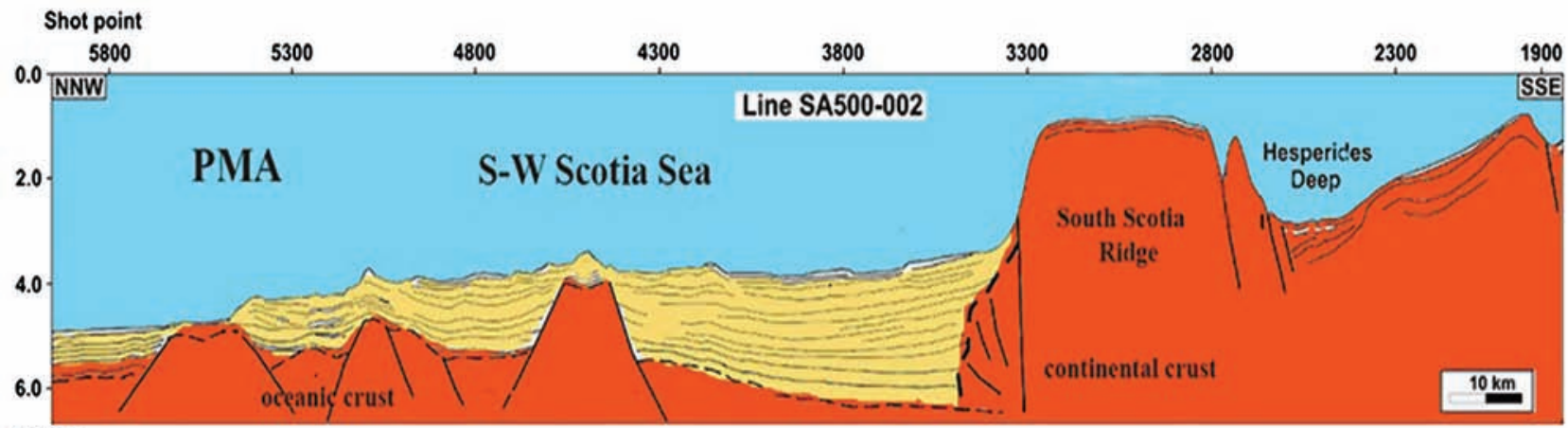

TWT,

Fig. 8 . Simplified bottom relief along seismic profile SA 500-002, by (Civile et al., 2012). Location of profile - on Fig. 1
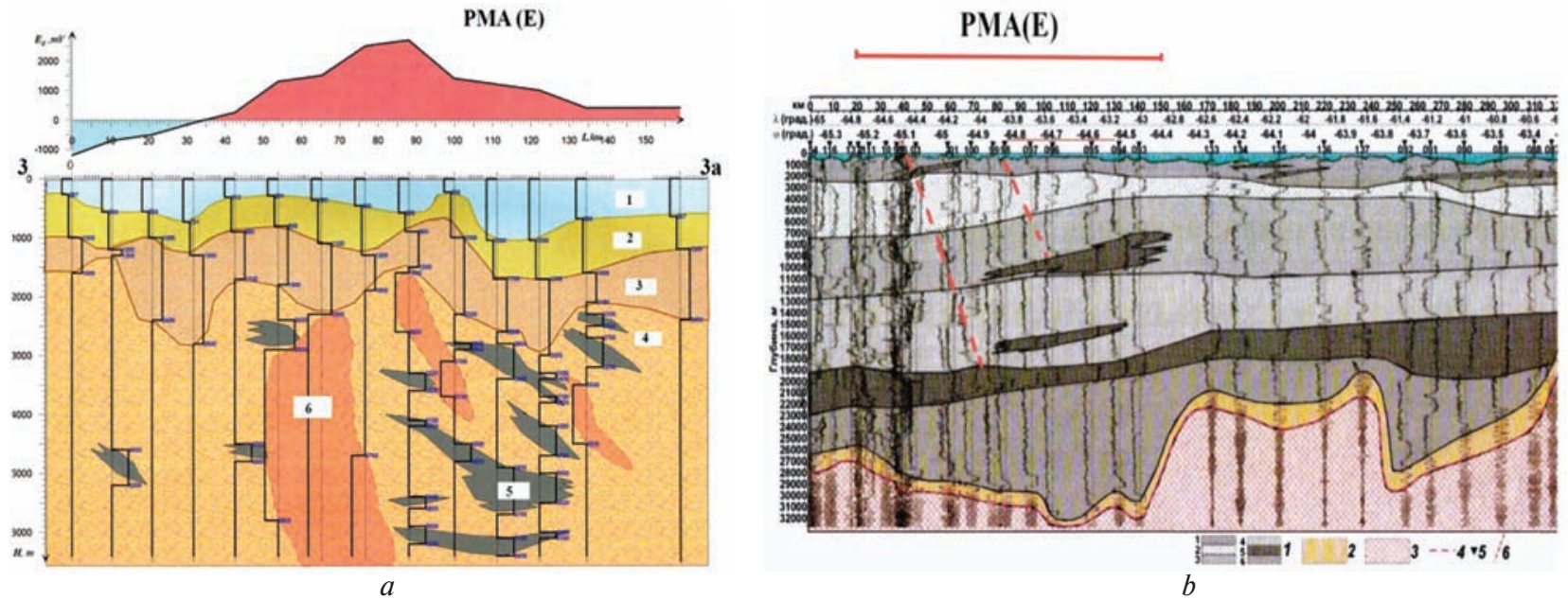

Fig. 9. $a$ - The crustal section along the profile 3-3a, by VERS. Legend: 1 water; 2 - first sedimentary layer; 3 - second sedimentary layer; 4 - basement rocks; 5 - blocks with high geoelectric resistance; 6 - blocks with low geoelectric resistance. Profile position - on Fig. $3 A, 4 A$. $b$ - Geoelectric section along the profile 5, by VERS-data. 1 - complex of volcanic and crystalline rocks; 2 - transition layer «crust-mantle»; 3 - rocks of the upper mantle; 4 - Moho discontinuity; 5 - VERS points; 6 - faults. Profile position - on Fig. 1 
The deep structure of the various blocks of the west part of the Antarctic Peninsula (within the PMA occurrence) has no fundamental differences that may indicate the existence of similar mechanism for their formation. The values of crustal thickness here (20$10 \mathrm{~km})$ are intermediate type and has been thinned and intruded by basalt rocks during rifting processes of different age. We suppose that the intensive magnetic anomalies distribution can be due to the formation of their deep sources as result of pulsations of the mantle matter and the Mesozoic - Cenozoic magmatic bodies (of basic composition) upwelling into the lithosphere structures with different crustal thickness.

\section{VERS-DATA AND PMA FEATURES}

New independent information about the inner structure and sources of PMA was obtained during seasonal works (Levashov et al., 2008, Soloviev et al., 2017). We have obtained more than 300 VERS (Vertical Electrical Resonanse Soundings) along some profiles across Drake Passage and Bransfield Strait for the deep crustal structure. Some specific geoelectric crustal boundaries reflect the result of real tectonic and magmatic activity processes at this region.

VERS-data show the detailed picture of the upper crust structure in the area of the eastern branch of PMA on 2-2a, 3-3a and 5-5a profiles position. Fault zone with $15-20 \mathrm{~km}$ wide separates the structures of external and internal shelves, confirming the previous results. It is likely that this fault has ancient and long history of formation, as indicated by the features of deep sections on profile 3-3a (Fig. 9). The dikes position at profiles coincides with the position of the magneto active body with magnetic susceptibility 0.065 SI units. The crust of continental shelf along the profile 3-3a (by VERS-data) has a complicated structure (Fig. 9). Over the PMA (E) branch in crustal section of profile there is a horizon of dykes $(80-145 \mathrm{~km}$, Fig. 9) at depths of 2.5 to $5.5 \mathrm{~km}$. Fault zone (50-80 km, Fig.9) separates this part of area from the outer shelf.

New features of deep structure of the continental shelf areas were found not only at the top of the crust (at depths of up to $6.0 \mathrm{~km}$ ) but at depths of 10.0-12.0 and 16.0-18.0 km (Fig. 9) where modelling section included many complex volcanic and crystalline rocks, and transition layer «crust-mantle» with variable thickness.

\section{CONCLUSIONS}

1. New geophysical models of the Earth's crust and upper mantle were used to study the possible nature of the Pacific Margin Anomaly (PMA) near the Antarctic Peninsula.

2. Active tectonic processes in the Mesozoic - Cenozoic resulted in the complex evolution and the magnetic sources of PMA along the AP margin forming. The PMA-batholith consists of a series of plutons with different ages, composition and magnetization. The magnetic sources of PMA along the AP margin were forming during not only Cretaceous, but also Paleogene to Neogene main phases of magmatic activity. Western and eastern branches of PMA have formed in the Early Cretaceous in structures, separated by a fault zone.

3. In the central part of the AP, between Anvers and the northern boundary of the Bransfield Strait, PMA splits into two branches - the western anomaly with relatively high and eastern anomalies with a relatively lower amplitude. The source of the western branch of the PMA can be a magnetic body (block or a group of blocks) with total width of about $80 \mathrm{~km}$, which lies at a depth of 5 to $25 \mathrm{~km}$ and has a magnetic susceptibility of 0.074 SI. The magnetic body, which is the source of the eastern branch of PMA, lies at a depth of 5-18 (20) km, has a magnetic susceptibility of $0.065 \mathrm{SI}$.

4. The branches of the PMA correspond to areas with different crustal thickness. This thickness is about $35 \mathrm{~km}$ under the eastern branch, and it is significantly $(10-15 \mathrm{~km})$ smaller under the western branch of the PMA. Western and eastern PMA branches may correspond to different crustal blocks associated with predominantly Cretaceous magmatic intrusions of basic rocks to the continental margin of the Antarctic Peninsula structures. These branches of PMA formed in the Early Cretaceous in structures, separated by a fault zone. The western branch of the PMA may be a Cretaceous allochthonous terrane. 
5. Spatial heterogeneity of the various segments of PMA can also be associated with a variety of depth, power and magnetic susceptibility of individual units that form the source of regional anomalies. It is possible that the total anomaly name (PMA) can formally integrate anomalies of different ages and origin. Numerous local young age intrusions form an additional PMA horizon of magnetized bodies associated with volcanic processes at the top of the crust. Some segments of the PMA may be associated with the processes of tectonic changes near the Antarctic - Scotia paleo-plate boundary, as well as processes in the areas of paleo rifts forming.

\section{REFERENCES}

1. Burton-Johnson, A., Riley, T. R. 2015. Autochthonous v. accreted terrane development of continental margins: a revised in situ tectonic history of the Antarctic Peninsula. Journal of the Geological Society, August 5. DOI:10.1144/ jgs 2014-110.

2. Catalan, M, Galindo-Zaldivar, J., Davila, J.M. et al. 2013. Initial stages of oceanic spreading in the Bransfield Rift from magnetic and gravity data analysis. Tectonophysics, 585, 102-112. 8 .

3. Civile, D., Lodolo, E., Vuan, A., and Loreto, F.M. 2012. Tectonics of the Scotia-Antarctica plate boundary constrained from seismic and seismological data. Tectonophysics, 550-553, 17-34.

4. Garrett, S.W. 1990. Interpretation of reconnaissance gravity and aeromagnetic surveys of the Antarctic Peninsula. J.Geophys. Res. , 95 (B5), 6759-6777.

5. Ferraccioli, F., Jones, P.C., Vaughan, A.P., Leat, P.T. 2006. New aerogeophysical view of the Antarctic Peninsula: more pieces, less puzzle. Geophys. Res. Lett., 33. DOI: 10.1029/ 2005 GL024636.

6. Ghidella, M.E., Forsberg, R., Greenbaum, J.S. et al. 2011. Magnetic anomaly data from a regional survey: from Tierra del Fuego to northern Palmer Land, Antarctic Peninsula. Latinmag Letters, 1, (A19), 1-7.

7. Golynsky, A., et al. 2012. Air and shipborne magnetic surveys of the Antarctic into the 21st century, Tectonophysics. DOI:10.1016/j.tecto.2012.02.017.

8. Golynsky, A.V. and V.N. Masolov. 1999. Interpretation of ground and aeromagnetic surveys of Palmer Land, Antarctic Peninsula. Annali di Geofisica, 42, 333-351.

9. Gràcia E., Canals M., Farràn , M. et al., 1996. Morphostructure and evolution of the Central and Eastern the Bransfield (NW Antarctic Peninsula). Marine Geophys. Res. 18, 429-448.
10. Johnson, A.C., 1999. Interpretation of new aeromagnetic anomaly data from central Antarctic Peninsula. J. Geophys. Res. 104, 5031-5046.

11. Jordan, T.A, Neale, R.F., Leat, P.T., et al. 2014. Structure and evolution of Cenozoic arc magmatism on the Antarctic Peninsula: a high resolution aeromagnetic perspective. Geophys. J. Int., 198, 1758-1774. DOI: 10.1093/gji/ggu233

12. Levashov, S.P., Yakymchuk, N.A., Korchagin, I.N. et al. 2008. Geophysical models of Drake Passage and Bransfield Strait crustal structure. Ukrainian Antarctic Journal, 6, 9-14.

13. Lodolo, E., Perez, L. F. 2015. An abandoned rift in the southwestern part of the South Scotia Ridge (Antarctica): Implications for the genesis of the Bransfield Strait. Tectonics, 34. DOI: 10.1002/2015TC004041.

14. Maslanyj, M.P., Garrett, S.W., Johnson, A.C. et al. 1991. Aeromagnetic anomaly map of West Antarctica, GEOMAP Series, Geophysical Map and Supplementary Text, British Antarctic Survey, Cambridge, 37.

15. Renner, R.G.B., Sturgeon, L.J.S. Garrett S.W. 1985. Reconnaissance gravity and aeromagnetic surveys of the Antarctic Peninsula. Brit. Antarct. Surv. Sci. Rep., 110, 50.

16. Shpyra, V., Bakhmutov V., Bakhmutova L.et al. 2014. Magnetic and density characteristics of igneous rocks near the Ukrainian station Akademik Vernadsky. Ukrainian Antarctic Journal, 13, 81-93. (in Russian).

17. Soloviev V., Korchagin I., Levashov S. et al. 2017. New geophysical data about the Pacific Margin Magnetic anomaly (PMA) sources and some features of the Western Antarctica geodynamic processes, 16th EAGE International Conference on Geoinformatics - Theoretical and Applied Aspects. DOI: 10.3997/2214-4609.201701827

18. Storey, B. C., Garrett, S.W. 1985. Crustal growth of the Antarctic Peninsula by accretion, magmatism and extension.Geol. Magazine, 122, 5-14.

19. Sushchevskaya, N.M., Migdisova, N.A., Dubinin, E.P. et al. 2016. Regional and local magmatic anomalies and tectonics of rift zones between the Antarctic and South American plates. Geochemistry International. 54, 6, 494-508.

20. Udintsev, G.B., Beresnev, A.F., Curentsova, N.A. et al. 2010. Drake Strait and Scotia Sea - oceanic gates of Western Antarctic (in Russian). Structure and history of development of lithosphere. Russian contribution to IPY. 4. Moscow. Paulsen. 66-90.

21. Vaughan, A.P.M., Livermore, R.A. 2005. Episodicity of Mesozoic terrane accretion along the Pacific margin of Gondwana: implications for superplume-plate interactions.in: Vaughan A.P.M, Leal P.T.,Punkhurst R.J.(Eds). Terrane Processes the Margins of Gondwana. Spec. Publ. Geol. Soc. of London, 246, 143-178.

22. Vaughan, A.P.M., Wareham, C.D., Johnson, A.C., Kelly, S.P. 1998. A lower Cretaceous, syn-extensional magmatic so-

ISSN 1727-7485. Ukrainian Antarctic Journal. 2018, № 1(17) 
urce for a linear belt of positive magmatic anomalies: the Pacific Margin Anomaly (PMA), western Palmer Land, Antarctica. Earth and Planetary Science Letters. 158, 143 155.

23. Yegorova, T., Bakhmutov, V. 2013. Crust structure of the Antarctic Peninsula sector of the Gondwana margin aro- und Anvers Island from geophysical data. Tectonophysics, $585,77-89$.

24. Yegorova, T., Bakhmutov, V., Janik, T. \& Grad, M. 2011. Joint geophysical and petrological models for the lithosphere structure of the Antarctic Peninsula continental marginm Geophys. J. Int., 184 (1), 90-110.

\section{В. Д. Соловйов ${ }^{1, *}$, В. Г. Бахмутов ${ }^{1,2}$, I. М. Корчагін ${ }^{1}$, Т. П. Сгорова ${ }^{1}$}

${ }^{1}$ Інститут геофізики ім. С. І. Субботіна, Національна академія наук України, м. Київ

2 Державна установа Національний антарктичний науковий центр МОН України, м. Київ

*Corresponding author: valera@igph.kiev.ua

\section{НОВІ ГЕОФІЗИЧНІ ДАНІ ПРО ДЖЕРЕЛА І ПОХОДЖЕННЯ МАГНІТНОЇ АНОМАЛІЇ ТИХООКЕАНСЬКОГО УЗБЕРЕЖЖЯ (ЗАХІДНА АНТАРКТИКА)}

РЕФЕРАТ. Під час проведення сезонних робіт в українських антарктичних експедиціях (1997-2012 рр.) був виконаний значний обсяг геолого-геофізичних досліджень з метою отримання нових даних про розподіл глибинних неоднорідностей в структурах регіону, що дозволило побудувати комплексні геофізичні моделі та доповнити наявні уявлення про етапи формування та еволюції тектонічних структур Західної Антарктики поблизу Антарктичного півострова (АП). Нові геофізичні моделі земної кори були використані для вивчення можливої природи магнітної аномалії Тихоокеанського узбережжя (РМА) поблизу Антарктичного півострова. Результати магнітних, сейсмічних і геоелектричних досліджень в районі Антарктичного півострова показали, що активні тектонічні процеси в мезо-кайнозої привели до формування магнітних джерел РМА уздовж краю АП. Просторову неоднорідність різних сегментів РМА можна пояснити різною глибиною, потужністю і магнітною сприйнятливістю окремих магнітоактивних тіл-джерел аномалій. Магнітоактивні джерела РМА в земній корі можуть бути обмеженими по глибині (до 8-10 км) і складатися з серії неоднорідно намагнічених тіл різного віку і складу. На форму аномалій РМА істотно впливають і численні локальні інтрузії, розташовані у верхній частині земної кори. В окремих сегментах РМА вони утворюють додатковий горизонт намагнічених тіл, пов'язаних з процесами молодого вулканізму в структурах континентальної окраїни. Висновки. Проаналізовано матеріали геофізичних зйомок і геолого-геофізичні моделі земної кори і верхньої мантії, які дозволили виявити особливості будови, еволюції та геодинамічних процесів розвитку структур регіону, а також отримати нові дані про можливу природу РМА. Прийнята назва протяжної магнітної аномалії (РМА) може формально об'єднувати аномалії різного віку і походження. Окремі сегменти РМА пов'язані з процесами тектонічних перетворень на палео-границях Антарктичної плити і плити Скоша, а також з особливостями формування структур в зонах палеорифтів. Отримані геофізичні результати для різних РМА-сегментів можуть бути використані для узагальнення сучасних уявлень про джерела і походження цієї позитивної магнітної аномалії.

Ключові слова: Західна Антарктика, Антарктичний півострів, магнітна аномалія Тихоокеанського узбережжя, геофізичні моделі, глибинна структура земної кори. 